DOI https://doi.org/10.30525/978-9934-26-110-7-27

\title{
ЗАСОБИ ВИРАЖЕННЯ КАТЕГОРІЇ ЧАСУ В АНГЛІЙСЬКІЙ МОВІ
}

\author{
Бакуменко О. О. \\ кандидат філологічних наук, \\ доцент кафедри іноземної філології та перекладу \\ Національний транспортний університет
}

\author{
Бондар А. Ю. \\ магістрантка \\ Національний транспортний університет \\ м. Київ, Україна
}

Категорії часу як поняттєвій категорії властивий універсальний характер [3, с. 63-64]. У мові часові поняття часто можуть знаходити своє відтворення у «лексичних одиницях темпоральної семантики та часових граматичних формах» [1, с. 17].

Граматична категорія часу, яка є особливим мовним відображенням об'єктивного часу, виражає відношення процесу до моменту мовлення (абсолютний час) або до часу іншого процесу у висловлюванні (відносний час) [7, с. 89].

Абсолютне вживання часових форм застосовується для того, щоб передати теперішнє (1), минуле (2), майбутнє (3), що не залежать від інших часових форм в реченні, а співвідносяться 3 моментом мовлення [2, c. 102-103]:

(1) Computer programs are now available that can iteratively optimize drug structures to fit known receptors [8, c. 4].

(2) The power of the matrix method of posture analysis was demonstrated in the previous section [10, c. 533];

(3) However, we will present a general procedure by which these variables can be determined [10, c. 535].

Відносне вживання часових форм передбачає співвіднесення дії 3 дією, вираженою іншою часовою формою (4), (5) [2, с. 102-103]:

(4) Of course, both these angels, and therefore the mechanical advantage, are continuously changing as the linkage moves [10, c. 37].

(5) His coworker notes that JM was working in a field that had been sprayed early in the morning with a material that had the odor of sulfur [8, c. 107]. 
У прикладі (4) має місце одночасність дій, а у реченні (5) передування іншій дії, виражене за допомогою Past Perfect.

У сучасній лінгвістиці визначено 16 часових форм, характерних для англійської мови [6, с. 87]. Past Indefinite вважається абсолютною часовою формою, а Continuous, Perfect i Perfect Continuous - відносними [2, c. 104].

Слід також відзначити, що в англійській мові семантика часу міцно пов'зана з характером перебігу дії. Враховуючи цю особливість, часові форми розподіляють за такими часово-видовими групами:

- неозначений або простий час Indefinite (може передавати послідовність дій, стан речей у певний час в теперішньому, минулому i майбутньому, не містить вказівки на тривалість, завершеність чи результативність);

- тривалий час Continuous (передає процес виконання дії в теперішньому, минулому або майбутньому);

- доконаний час Perfect (виражає дію, що завершилася до певного моменту в теперішньому, минулому чи майбутньому або до початку іншої дії);

- доконано-тривалий час Perfect Continuous (позначає процес, який почався до певного моменту в теперішньому, минулому чи майбутньому, триває або завершився до того моменту [5, с. 275-277].

До лексичних засобів вираження часу належать слова із семантикою темпоральності. Зокрема, це - іменники на позначення:

- відрізків часу: second, minute, hour, day, night, morning, evening, dawn, dusk, twilight тощо;

- днів тижня: Sunday, Wednesday, Thursday, Saturday;

- місяців: January, April, May, June, September, October, December;

- пори року: winter, spring, summer, autumn;

- свят: New Year's Day, Independence Day, Thanksgiving Day, Washington's Birthday тощо.

Інші частини мови також можуть мати семантику темпоральності: прикметники (past, last, late, previous, ancient, coming, following, present тощо), прислівники (ago, previously, earlier, before, now), дієслова та іменники із семою «час» (a memory, to remember, to forget) [1, с. 20].

Показниками часу можуть також слугувати й прийменники. Так, наприклад, прийменник in вживається $[4$, c. 6]:

- зі значенням «в», «у» для позначення місяця чи року: She will come back in February.

- зі значенням «за», «через»: He will return in an hour. 
- зі значенням «за», «протягом»: I have prepared for my exam in three days.

Варто зазначити, що при позначенні часу in вживається для вказування періоду (in March, in 2005), а at - для вказування моменту (at three o'clock, at midnight, at noon) [4, c. 31].

Значення граматичних часових форм часто підсилюється за допомогою лексичних засобів. Наприклад, семантика Present Perfect Continuous у наступних прикладах набуває більшого вираження за допомогою слова since, що вказує на початок періоду, протягом якого відбувалася дія. В реченні since може вживатися як:

- прийменник: Since 2006, I've been a computer operator for PromoPrint [9, c. 132].

- прислівник: She moved here in 1995. She has been teaching history at our school since.

- сполучник: What have you been doing since you left the mine?

Наведені приклади свідчать про різноманіття засобів вираження категорії часу, необхідність вивчення особливостей їхньої взаємодії. Грунтовне вивчення засобів вираження категорії часу в англійській мові в свою чергу уможливить розуміння сутності і функціонування мовних явищ, що сприятиме вдосконаленню володіння мовою, професійному зростанню майбутнього вчителя, дослідника і перекладача.

\section{Література:}

1. Гошилик Н. С. Схемні образи часу в сучасній англійській мові: монографія. Івано-Франківськ: НАІР, 2013. 220 с.

2. Гусева Е. Н. Типы употребления форм времени русского и английского языков в сопоставительном аспекте. Вестник науки $u$ образования. 2017. № 4 (28). С. 102-104.

3. Іщенко Н. Г. Семантична та поняттєва категорії у мовознавчих студіях. Вісник Національного технічного університету Украӥни «Київський політехнічний інститут». Серія : Філологія. Педагогіка. 2013. Вип. 2. С. 61-64.

4. Калашніков Г. Д. Прийменники англійської мови: Методична розробка для студентів 1-го курсу денної форми навчання освітньокваліфікаційного рівня бакалавр Інституту міжнародного бізнесу та менеджменту. Тернопіль: ТДЕУ, 2005. 64 с.

5. Камянова Т. Г. English Grammar. Грамматика английского языка: теория и практика: в 2 т. Москва: Эксмо, 2017. Ч. 1: Теоретическая грамматика. $768 \mathrm{c}$. 
6. Ніконорова Л. І., Стогній І. В. Вживання часових форм дієслова в англійській мові. Науковий вісник Національної академії статистики, обліку та аудиту. 2015. № 2. С. 86-90.

7. Языкознание: большой энциклопедический словарь / под ред. В. Н. Ярцевой. Москва: Большая Российская энциклопедия, 2000. 688 с.

8. Katzung B. G. Basic And Clinical Pharmacology 14th Edition. New York: McGraw-Hill Education, 2018. 1250 p.

9. Remacha Esteras S. Infotech. English for Computer Users. Student's book. 4th Edition. Cambridge University Press. 2008. 172 p.

10. Uicker J. J. Pennock G. R., Shigley J. E. Theory of machines and mechanisms. New York, Oxford: Oxford University Press, 2017. 945 p.

DOI https://doi.org/10.30525/978-9934-26-110-7-28

\title{
СТРУКТУРНО-СЕМАНТИЧНІ ОСОБЛИВОСТІ ЕПIГРАМ ЕРIXА КЕСТНЕРА
}

\author{
Бандурко 3. В. \\ кандидат філологічних наук, \\ старший викладач кафедри німеиької та романської філології \\ Херсонський державний університет \\ м. Херсон, Украӥна
}

Культура та література Веймарської республіки є багатогранним та цікавим феноменом у літературі Німеччини XX століття. 3-поміж чисельних стилів та течій цього періоду визначне місце займає напрям «Нова діловитість» (,Neue Sachlichkeit»), одним із найвідоміших представників якого $є$ Еріх Кестнер. У цей час зазнають розвитку та видозмін вже існуючі жанри, зокрема роман, та створюються нові - від репортажних романів до репортажної драми, дитячого роману, радіоповідомлень, вживаної лірики (,,Gebrauchslyrik») тощо [1, с. 177; 2, с. 58; 3].

Окрему частину творчості Еріха Кестнера становлять ліричні твори, у тому числі епіграми. Епіграму розуміємо як «жанр сатиричної поезії дотепного, дошкульного змісту з несподіваною, градаційно завершеною кінцівкою (пуантом) [4, с. 233].

Для епіграм Еріха Кестнера (Kr.) властиві лаконічність, філософічність, зображення лише головної думки чи основних подій. Епіграми збірки „Еs gibt nichts Gutes, außer: Man tut es: Kurz und bündig. Epigramme» [5] є здебільшого філософськими за своїм змістом, але 